\title{
PREDICTIONS OF COVID-19 PANDEMIC DYNAMICS IN UKRAINE AND QATAR BASED ON GENERALIZED SIR MODEL
}

\author{
I. Nesteruk ${ }^{1,2^{*}}$, N. Benlagha ${ }^{3}$ \\ ${ }^{1}$ Institute of Hydromechanics, National Academy of Sciences of Ukraine, Kyiv, Ukraine \\ ${ }^{2}$ Igor Sikorsky Kyiv Polytechnic Institute, Kyiv, Ukraine \\ ${ }^{3}$ Qatar University, Doha, Qatar \\ *Corresponding author: inesteruk@yahoo.com
}

Received 4 March 2021; Accepted 24 March 2021

\begin{abstract}
Background. To simulate how the number of COVID-19 cases increases versus time, various data sets and different mathematical models can be used. Since there are some differences in statistical data, the results of simulations can be different. Complex mathematical models contain many unknown parameters, the values of which must be determined using a limited number of observations of the disease over time. Even longterm monitoring of the epidemic may not provide reliable estimates of the model parameters due to the constant change of testing conditions, isolation of infected, quarantine conditions, pathogen mutations, vaccinations, etc. Therefore, simpler approaches are necessary. In particular, previous simulations of the COVID-19 epidemic dynamics in Ukraine were based on smoothing of the dependence of the number of cases on time and the generalized SIR (susceptible-infected-removed) model. These approaches allowed detecting the pandemic waves and calculating adequate predictions of their duration and final sizes. In particular, eight waves of the COVID-19 pandemic in Ukraine were investigated.

Objective. We aimed to detect the changes in the pandemic dynamics and present the results of SIR simulations based on Ukrainian national statistics and data reported by Johns Hopkins University (JHU) for Ukraine and Qatar.

Methods. In this study we use the smoothing method for the dependences of the number of cases on time, the generalized SIR model for the dynamics of any epidemic wave, the exact solution of the linear differential equations, and statistical approach for the model parameter identification developed before.

Results. The optimal values of the SIR model parameters were calculated and some predictions about final sizes and durations of the epidemics are presented. Corresponding SIR curves are shown and compared with the real numbers of cases.

Conclusions. Unfortunately, the forecasts are not very optimistic: in Ukraine, new cases will not stop appearing until June-July 2021; in Qatar, new cases are likely to appear throughout 2021. The expected long duration of the pandemic forces us to be careful and in solidarity. Probably the presented results could be useful in order to estimate the efficiency of vaccinations.

Keywords: COVID-19 pandemic; epidemic dynamics in Ukraine; epidemic dynamics in Qatar; mathematical modeling of infection diseases; SIR model; parameter identification; statistical methods.
\end{abstract}

\section{Introduction}

The studies of the COVID-19 pandemic dynamics in Ukraine are presented in [1-3] and summarized in the book [4]. Some SEIR (susceptible-exposed-infected-removed) and SEIRD (susceptible-exposed-infected-removed-dead) simulations of the pandemic dynamics in Qatar can be found in $[5,6]$. For Ukraine, different simulation and comparison methods were based on official accumulated number of laboratory confirmed cases [7, 8] (national statistics). These figures coincides with the official WHO data sets [9]. Unfortunately, WHO stopped to provide the daily information in August 2020. In this study we will use also the information from COVID-19 Data Repository by the
Center for Systems Science and Engineering (CSSE) at Johns Hopkins University (JHU) [10].

The classical SIR model [11, 12], connecting the number of susceptible $S$, infected and spreading the infection $I$ and removed $R$ persons, was applied in $[1,4]$ to simulate the first pandemic wave in Ukraine. The unknown parameters of this model were estimated with the use of the cumulative number of cases $V=I+R$ and the statisticsbased method of parameter identification developed in $[1,4]$.

The weakening of quarantine restrictions, changes in the social behavior and the coronavirus activity causes change in SIR characteristics and the epidemic dynamics. To detect these changes, a simple method of numerical differentiations of 
accumulated number of cases was proposed in $[2,4]$. To simulate these new pandemic waves, the SIR model was generalized in $[2-4]$. In $[2,4]$ the results of simulation of the first six epidemic waves in Ukraine are presented with the use of a procedure for sequentially determining the parameters of the model for each epidemic wave, starting with the first one.

This method requires considerable efforts and time. The book [4] introduced a new algorithm for determining the optimal parameter values for a particular epidemic wave without calculating the dynamics of previous waves and presented calculations for the seventh epidemic wave in Ukraine. The eighth epidemic wave in Ukraine were simulated in [3] with the use of this approach. In this paper, we will analyze the dynamics of the epidemic in Ukraine and Qatar in the period from December 1, 2020 to February 20, 2021 and make some predictions.

\section{Materials and Methods}

\section{Data}

We will use two data sets regarding the accumulated numbers of confirmed COVID-19 cases in Ukraine: the official information from national sources [7, 8] $-V_{j 1}$ and data set $V_{j 2}$ from the COVID-19 Data Repository by the Center for Systems Science and Engineering (CSSE) at Johns Hopkins University (JHU) [10]. These values and corresponding moments of time $t_{j}$ (measured in days, zero point is November 30,2020) are shown in Table 1.

\section{Detection of epidemic waves}

To control the changes of epidemic parameters, we can use daily numbers of new cases and their derivatives. Since these values are random, we need some smoothing. For example, we can use the smoothed daily number of accumulated cases proposed in [2-4]:

$$
\bar{V}_{i}=\frac{1}{7} \sum_{j=i-3}^{j=i+3} V_{j} .
$$

The first and second derivatives can be estimated with the use of following formulas:

$$
\begin{gathered}
\left.\frac{d \bar{V}}{d t}\right|_{t=t_{i}} \approx \frac{1}{2}\left(\bar{V}_{i+1}-\bar{V}_{i-1}\right), \\
\left.\frac{d^{2} \bar{V}}{d t^{2}}\right|_{t=t_{i}} \approx \bar{V}_{i+1}-2 \bar{V}_{i}+\bar{V}_{i-1} .
\end{gathered}
$$

\section{Generalized SIR model}

The classical SIR model for an infectious disease $[11,12]$ was generalized in $[2-4]$ to simulate different epidemic waves. We suppose that the SIR model parameters are constant for every epidemic wave, i.e. for the time periods:

$$
t_{i}^{*} \leq t \leq t_{i+1}^{*}, i=1,2,3, \ldots
$$

Then for every wave we can use the equations, similar to $[11,12]$ :

$$
\begin{gathered}
\frac{d S}{d t}=-\alpha_{i} S I, \\
\frac{d I}{d t}=\alpha_{i} S I-\rho_{i} I, \\
\frac{d R}{d t}=\rho_{i} I,
\end{gathered}
$$

where $S$ is the number of susceptible persons (who are sensitive to the pathogen and not protected); $I$ is the number of infected persons (who are sick and spread the infection; please don't confuse with the number of still ill persons, so known active cases) and $R$ is the number of removed persons (who no longer spread the infection; this number is the sum of isolated, recovered, dead, and infected people who left the region). Parameters $\alpha_{i}$ and $\rho_{i}$ are supposed to be constant for every epidemic wave.

Parameters $\alpha_{i}$ show how quick the susceptible persons become infected (see (4)). Large values of this parameter correspond to severe epidemics with many victims. These parameters accumulate many characteristics. First they shows how strong (virulent) is the pathogen and what is the way of its spreading. Parameters $\alpha_{i}$ accumulate also the frequency of contacts and the way of contacting. In order to decrease the values of $\alpha_{i}$, we have to minimize the number of our contacts and change our contacting habits. For example, we have to avoid the public places and use masks there, minimize or cancel traveling. We have to change our contact habits: to avoid handshakes and kisses. First, all these simple things are very useful to protect yourself. In addition, if most people follow these recommendations, we have chance to diminish the values of parameters $\alpha_{i}$ and reduce the negative effects of the pandemic.

The parameters $\rho_{i}$ characterize the patient removal rates, since eq. (6) demonstrates the increase rate of $R$. The inverse values $1 / \rho_{i}$ are the 
Table 1: Cumulative numbers of confirmed Covid-19 cases in Ukraine and Qatar

\begin{tabular}{|c|c|c|c|c|c|c|c|c|c|c|}
\hline $\begin{array}{c}\text { Day in } \\
\text { December } \\
2020 \\
t_{j}\end{array}$ & $\begin{array}{l}\text { NC in } \\
\text { Ukraine, } \\
\text { National } \\
\text { statistics } \\
{[7,8] V_{j 1}}\end{array}$ & $\begin{array}{l}\text { NC in } \\
\text { Ukraine, } \\
\text { JHU } \\
{[10] V_{j}}\end{array}$ & $\begin{array}{c}\text { NC in Qatar, } \\
\text { JHU } \\
{[10] V_{j 3}}\end{array}$ & $\begin{array}{c}\text { Day in } \\
\text { January } \\
2021\end{array}$ & $\begin{array}{c}\text { NC in Ukraine, } \\
\text { National } \\
\text { statistics } \\
{[7,8] V_{j 1}}\end{array}$ & $\begin{array}{c}\mathrm{NC} \text { in } \\
\text { Ukraine, } \\
\underset{V_{j 2}}{\mathrm{JHU}}[10]\end{array}$ & $\begin{array}{c}\text { NC in Qatar, } \\
\text { JHU } \\
{[10] V_{j 3}}\end{array}$ & $\begin{array}{l}\text { Day in } \\
\text { February } \\
2021\end{array}$ & $\begin{array}{l}\text { NC in } \\
\text { Ukraine, } \\
\text { National } \\
\text { statistics } \\
{[7,8] V_{j 1}}\end{array}$ & $\begin{array}{c}\text { NC in Qatar, } \\
\text { JHU } \\
{[10] V_{j 3}}\end{array}$ \\
\hline 1 & 758264 & 765117 & 139001 & 1 & 1069517 & 1096855 & 144042 & 1 & 1223879 & 151720 \\
\hline 2 & 772760 & 778560 & 139256 & 2 & 1074093 & 1102256 & 144240 & 2 & 1227164 & 152095 \\
\hline 3 & 787891 & 793372 & 139477 & 3 & 1078251 & 1107137 & 144437 & 3 & 1232246 & 152491 \\
\hline 4 & 801716 & 808828 & 139643 & 4 & 1083585 & 1111631 & 144644 & 4 & 1237169 & 152898 \\
\hline 5 & 813306 & 822985 & 139783 & 5 & 1090496 & 1117256 & 144852 & 5 & 1241479 & 153296 \\
\hline 6 & 821947 & 834913 & 139908 & 6 & 1099493 & 1124482 & 145061 & 6 & 1244849 & 153690 \\
\hline 7 & 832758 & 843898 & 140086 & 7 & 1105169 & 1133802 & 145271 & 7 & 1246990 & 154098 \\
\hline 8 & 845343 & 855054 & 140203 & 8 & 1110015 & 1139800 & 145466 & 8 & 1249646 & 154525 \\
\hline 9 & 858714 & 867991 & 140353 & 9 & 1115026 & 1144943 & 145672 & 9 & 1253055 & 155002 \\
\hline 10 & 872228 & 881727 & 140516 & 10 & 1119314 & 1150265 & 145865 & 10 & 1258094 & 155453 \\
\hline 11 & 885039 & 895620 & 140680 & 11 & 1124430 & 1154850 & 146068 & 11 & 1262867 & 155901 \\
\hline 12 & 894215 & 908839 & 140827 & 12 & 1130839 & 1160243 & 146279 & 12 & 1268049 & 156351 \\
\hline 13 & 900666 & 918444 & 140961 & 13 & 1138764 & 1166958 & 146480 & 13 & 1271143 & 156804 \\
\hline 14 & 909082 & 925321 & 141121 & 14 & 1146963 & 1175343 & 146689 & 14 & 1273475 & 157244 \\
\hline 15 & 919704 & 934161 & 141272 & 15 & 1154692 & 1183963 & 146885 & 15 & 1276618 & 158132 \\
\hline 16 & 931751 & 945218 & 141417 & 16 & 1160682 & 1192114 & 147089 & 16 & 1280904 & 158138 \\
\hline 17 & 944381 & 957692 & 141557 & 17 & 1163716 & 1198512 & 147277 & 17 & 1287141 & 158591 \\
\hline 18 & 956123 & 970758 & 141716 & 18 & 1167655 & 1201894 & 147504 & 18 & 1293672 & 159053 \\
\hline 19 & 964448 & 982937 & 141858 & 19 & 1172038 & 1206125 & 147729 & 19 & 1299967 & 159518 \\
\hline 20 & 970993 & 991700 & 142001 & 20 & 1177621 & 1210854 & 148000 & 20 & 1304456 & 159967 \\
\hline 21 & 979506 & 998678 & 142159 & 21 & 1182969 & 1216780 & 148258 & - & - & - \\
\hline 22 & 989642 & 1007627 & 142308 & 22 & 1187897 & 1222459 & 148521 & - & - & - \\
\hline 23 & 1001132 & 1018199 & 142448 & 23 & 1191812 & 1227723 & 148772 & - & - & - \\
\hline 24 & 1012167 & 1030125 & 142605 & 24 & 1194328 & 1231965 & 149019 & - & - & - \\
\hline 25 & 1019876 & 1041583 & 142734 & 25 & 1197107 & 1234772 & 149296 & - & - & - \\
\hline 26 & 1025989 & 1049717 & 142903 & 26 & 1200883 & 1237810 & 149595 & - & - & - \\
\hline 27 & 1030374 & 1056265 & 143062 & 27 & 1206412 & 1241863 & 149933 & - & - & - \\
\hline 28 & 1037362 & 1061074 & 143222 & 28 & 1211593 & 1247674 & 150280 & - & - & - \\
\hline 29 & 1045348 & 1068476 & 143428 & 29 & 1216278 & 1253127 & 150621 & - & - & - \\
\hline 30 & 1055047 & 1076880 & 143621 & 30 & 1219455 & 1258093 & 150984 & - & - & - \\
\hline 31 & 1064479 & 1086997 & 143834 & 31 & 1221485 & 1261546 & 151335 & - & - & - \\
\hline
\end{tabular}

Notes. NC denotes the number of cases. $V_{j 1}$ - National statistics [7, 8], $V_{j 2}$ and $V_{j 3}-$ according to COVID-19 Data Repository by the Center for Systems Science and Engineering (CSSE) at Johns Hopkins University (JHU) [10]. 
estimations for time of spreading infection $\tau_{i}$ during $i$-th epidemic wave. So, we are interested in increasing the values of parameters $\rho_{i}$ and decreasing $1 / \rho_{i}$. People and public authorities should work on this and organize immediate isolation of suspicious cases.

Since the derivative $d(S+I+R) / d t$ is equal to zero (it follows from summarizing Eqs. (4)-(6)), the sum

$$
N_{i}=S+I+R
$$

must be constant for every wave and is not the volume of population.

To determine the initial conditions for the set of equations (4)-(6), let us suppose that at the beginning of every epidemic wave $t_{i}^{*}$ :

$$
I\left(t_{i}^{*}\right)=I_{i}, \quad R\left(t_{i}^{*}\right)=R_{i}, \quad S\left(t_{i}^{*}\right)=N_{i}-I_{i}-R_{i} .
$$

It follows from (4) and (5) that

$$
\frac{d I}{d S}=\frac{v_{i}}{S}-1, \quad v_{i}=\frac{\rho_{i}}{\alpha_{i}} .
$$

Integration of (9) with the initial conditions (8) and taking into account (7) yields:

$$
I=v_{i} \ln S-S+N_{i}-R_{i}-v_{i} \ln \left(N_{i}-I_{i}-R_{i}\right) .
$$

It follows from (9) that function $I$ has a maximum at $S=v_{i}$ and tends to zero at infinity. The corresponding number of susceptible persons at infinity $S_{i \infty}>0$ can be calculated from the nonlinear equation:

$$
S_{i \infty}=\left(N_{i}-I_{i}-R_{i}\right) e^{\frac{S_{i \infty}-N_{i}-R_{i}}{v}} .
$$

Formula (11) follows from (10) at $I=0$.

In [2-4] the set of differential equations (4)(6) was solved by introducing the function

$$
V(t)=I(t)+R(t),
$$

corresponding to the number of victims or the cumulative confirmed number of cases. For many epidemics (including the COVID-19 pandemic) we cannot observe dependencies $S(t), I(t)$ and $R(t)$ but observations of the accumulated number of cases $V_{j}$ corresponding to the moments of time $t_{j}$ provide information for direct assessments of the dependence $V(t)$.

It follows from (5) and (6) that:

$$
\frac{d V}{d t}=\alpha_{i} S I
$$

Eqs. (7), (10) and (13) yield:

$$
\begin{gathered}
\frac{d V}{d t}=\alpha_{i}\left(N_{i}-V\right) G_{i}(V), \\
G_{i}(V)=v_{i} \ln \left(N_{i}-V\right)+V-R_{i}-v_{i} \ln \left(N_{i}-R_{i}-I_{i}\right) .
\end{gathered}
$$

Integration of (14) provides an analytical solution for the set of equations (4)-(6):

$$
\begin{gathered}
F_{i}^{*}\left(V, N_{i}, I_{i}, R_{i}, v_{i}\right)=\alpha_{i}\left(t-t_{i}^{*}\right), \\
F_{i}^{*}=\int_{R_{i}+I_{i}}^{V} \frac{d U}{\left(N_{i}-U\right) G_{i}(U)} .
\end{gathered}
$$

Thus, for every set of parameters $N_{i}, I_{i}, R_{i}$, $v_{i}, \alpha_{i}$ and a fixed value of $V$, integral (16) can be calculated and the corresponding moment of time can be determined from (15). Then functions $I(t)$ and $R(t)$ can be easily calculated with the use of formulas (10) and:

$$
S=N_{i}-V, R=V-I .
$$

The final numbers of victims (final accumulated number of cases corresponding to the $i$-th epidemic wave) can be calculated from:

$$
V_{i \infty}=N_{i}-S_{i \infty} .
$$

To estimate the final day of the $i$-th epidemic wave, we can use the condition:

$$
I\left(t_{i f}\right)=1
$$

which means that at $t>t_{i f}$ less than one person still spreads the infection.

\section{Parameter identification procedure}

In the case of a new epidemic, the values of its parameters are unknown and must be identified with the use of limited data sets. For the first wave of an epidemic starting with one infected person, the number of unknown parameters is only four, since $I_{1}=1$ and $R_{1}=0$. The corresponding statistical approach was used in $[1,4]$ to simulate the first COVID-19 pandemic wave in Ukraine and many other countries.

For the next epidemic waves $(i>1)$, the moments of time $t_{i}^{*}$ corresponding to their beginning are known. Therefore the exact solution (15)-(17) depends only on five parameters $-N_{i}, I_{i}, R_{i}, v_{i}, \alpha_{i}$. 
Then the registered number of victims $V_{j}$ corresponding to the moments of time $t_{j}$ can be used in eq. (16) in order to calculate

$$
F_{i, j}=F_{i}^{*}\left(V_{j}, N_{i}, v_{i}, I_{i}, R_{i}\right)
$$

for every fixed values of $N_{i}, v_{i}, I_{i}, R_{i}$ and then to check how the registered points fit the straight line (15).

Eq. (15) can be rewritten as follows:

$$
y \equiv F_{i}^{*}\left(V, N_{i}, I_{i}, R_{i}, v_{i}\right)=\alpha_{i} t-\alpha_{i} t_{i}^{*} .
$$

Assuming

$$
\gamma=\alpha_{i}, \quad \beta=-\alpha_{i} t_{i}^{*}
$$

we can estimate the values of parameters $\gamma$ and $\beta$, by treating the values $y_{j} \equiv F_{i}^{*}\left(V_{i}, N_{i}, I_{i}, R_{i}, v_{i}\right)$ and corresponding time moments $t_{j}$ as random variables Then we can use the observations of the accumulated number of cases and the linear regression in order to calculate the coefficients $\hat{\gamma}$ and $\hat{\beta}$ of the regression line

$$
\widehat{y}=\widehat{\gamma} t+\widehat{\beta}
$$

using the standard formulas from, e.g., [13]. Values $\hat{\gamma}$ and $\hat{\beta}$ can be treated as statistics-based estimations of parameters $\gamma$ and $\beta$ from relationships (21).

The reliability of the method can be checked by calculating the correlation coefficients $r_{i}$ (see e.g., [13]) for every epidemic wave and checking how close its value is to unity. We can use also the $F$-test for the null hypothesis that says that the proposed linear relationship (20) fits the data set. The experimental values of the Fisher function can be calculated for every epidemic wave with the use of the formula

$$
F_{i}=\frac{r_{i}^{2}\left(n_{i}-m\right)}{\left(1-r_{i}^{2}\right)(m-1)}
$$

where $n_{i}$ is the number of observations for the $i$-th epidemic wave, $m=2$ is the number of parameters in the regression equation. The corresponding experimental value $F_{i}$ has to be compared with the critical value $F_{C}\left(k_{1}, k_{2}\right)$ of the Fisher function at a desired significance or confidence level $\left(k_{1}=m-1\right.$, $k_{2}=n_{i}-m$ ). When the values $n_{i}$ and $m$ are fixed, the maximum of the Fisher function coincides with the maximum of the correlation coefficient. Therefore, to find the optimal values of parameters
$N_{i}, v_{i}, I_{i}, R_{i}$, we have to find the maximum of the correlation coefficient for the linear dependence (20). To compare the reliability of different predictions (with different values of $n_{i}$ ) it is useful to use the ratio $F_{i} / F_{C}\left(1, n_{i}-2\right)$ at fixed significance level. We will use the level 0.001 ; corresponding values of $F_{C}\left(1, n_{i}-2\right)$ can be taken from [14]. The most reliable prediction yields the highest $F_{i} / F_{C}\left(1, n_{i}-2\right)$ ratio.

The exact solution (15)-(17) allows avoiding numerical solutions of differential equations (4)-(6) and significantly reduce the time spent on calculations. In the case of sequential calculation of epidemic waves $i=1,2,3 \ldots$, it is possible to avoid determining the four optimal unknown parameters $N_{i}, v_{i}, I_{i}, R_{i}$, thereby reducing the amount of calculations and difficulties in isolation a maximum of the correlation coefficient. For parameters $I_{i}, R_{i}$ it is possible to use the numbers of $I$ and $R$ calculated for the previous wave of epidemic at the moment of time when the following wave began. Then we need to calculate values $F_{i}^{*}\left(V_{i}, N_{i}, v_{i}\right)$, linear regression coefficients (22), correlation coefficient $r_{i}, F_{i} / F_{C}(1, n-2)$ and to isolate the values of parameters $N_{i}$ and $v_{i}$ corresponding to the maximum of $r_{i}$. Knowing the optimal values of five parameters $N_{i}, I_{i}, R_{i}, v_{i}, \alpha_{i}$, the SIR curves and other characteristics of the corresponding epidemic wave can be calculated with the use of formulas (10)-(17). This approach has been successfully used in $[2,4]$. In particular, six waves of the Covid-19 epidemic in Ukraine and four pandemic waves in the world were calculated.

Segmentation of epidemic waves and their sequential SIR simulations need a lot of efforts. To avoid this, a new method of obtaining the optimal values of SIR parameters was proposed in [3, 4]. First of all we can use the relationship

$$
V_{i}=I_{i}+R_{i}
$$

which follows from (12). To estimate the value $V_{i}$, we can use the smoothed accumulated number of cases (e.g., formula (1)). Then

$$
V_{i} \approx \frac{1}{7} \sum_{j=i-3}^{j=i+3} V_{j}
$$

where $i$ corresponds to the moment of time $t_{i}^{*}$. To obtain one more relationship, let us use (7) and (13) 


$$
I_{i}=\left.\frac{1}{\alpha_{i}\left(N_{i}-V_{i}\right)} \frac{d V}{d t}\right|_{t=t_{i}^{*}}
$$

To estimate the average number of new cases $d V / d t$ at the moment of time $t_{i}^{*}$, we can use (2). Thus the dependences (24)-(26) allow us to have only two independent parameters $N_{i}$ and $v_{i}$. To calculate the value of parameter $\alpha_{i}$, some iterations can be used (see details in [4]).

\section{Results}

The COVID-19 pandemic characteristics for Ukraine and Qatar after December 1, 2020 are shown in Figs. 1 and 2. "Circles", "triangles", and "stars" correspond to the accumulated numbers during period of time taken for SIR simulations $T_{c}$ : December 11-24, before $T_{c}$, and after $T_{c}$, respectively. The derivatives of the smoothed number of cases (see eq. (1)) are represented by "crosses" (the first derivative, eq. (2)) and "dots" (the second derivative, eq. (3)). In Fig. 1, the red color corresponds to the Ukrainian national statistics [7,8]; black to JHU data [10]. There is significant differences in two data sets visible in Fig. 1. The numbers of cases reported by JHU in January 2021 are $30,000-40,000$ higher than those presented by the national statistics $[7,8]$. However, both data sets are probably incomplete. We will discuss this issue later.

"Dots" in Fig. 2 illustrate some increases in the second derivatives in late December and after the middle of January, which can be treated as the new epidemic waves in Qatar. The increase in the average number of new cases ("crosses" in Fig. 2 showing the values of the first derivative (2)) confirm this conclusion. Severe jumps of the second derivative on February 11-12 are probably caused by data irregularities.

The results of SIR simulations are shown in Table 2 and Figs. 1 and 2. Since eight epidemic wave was already calculated for Ukraine [1-4], we took the period $T_{c}$ : December 11-24, 2020 to calculate the ninth epidemic wave in Ukraine with the use of two datasets (presented in Table 1). We have used the same period $T_{c}$ and the JHU data set (see Table 1) to calculate the optimal parameters of SIR model and other epidemic characteristics for Qatar. Since previous epidemic waves in this country were not simulated before, we use the name "second" for this wave. The number of observations taken for calculations $n_{i}$ was 14 in all the cases.

It can be seen that two data sets yield rather different values of the optimal parameters for the ninth epidemic wave in Ukraine (especially for $N_{9}$, $S_{9 \infty}$, and $v_{9}$ ), nevertheless the final sizes of this wave $V_{9 \infty}$ and $\rho_{9}$ are rather close; the duration based on the national statistics is one month longer in comparison with the calculations based on JHU data set. Both simulations for the ninth epidemic wave in Ukraine yield slightly higher final sizes in comparison with the eighth wave calculated in [3].

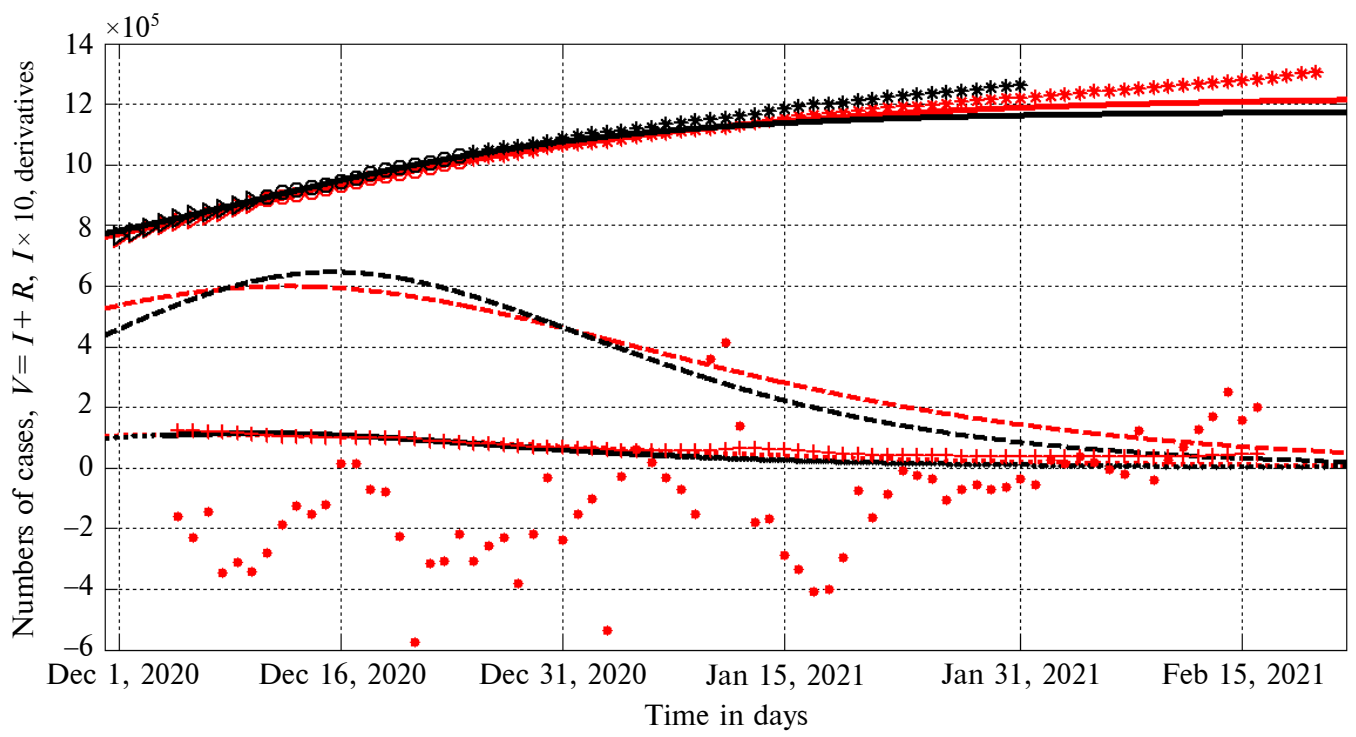

Figure 1: Pandemic dynamics in Ukraine (markers) and SIR simulations (lines) calculated with the use of data sets from Tables 1 and 2: national statistics [7, 8] (red) and data set reported by JHU [10] (black). Numbers of victims $V(t)=I(t)+R(t)-$ solid lines; numbers of infected and spreading $I(t)$ multiplied by 10 - dashed; derivatives $d V / d t$ (eq. (13)) multiplied by $10-$ dotted. Markers show accumulated numbers of cases $V_{j 1}$ and $V_{j 2}$ from Table 1 and derivatives. "Circles" correspond to the accumulated numbers of cases taken for calculations (during period of time $T_{c}$ ); "triangles" - numbers of cases before $T_{c}$; "stars" - number of cases after $T_{c}$. "Crosses" show the first derivatives (eq. (2)) multiplied by 10, "dots" - the second derivative (eq. (3)) multiplied by 1000 


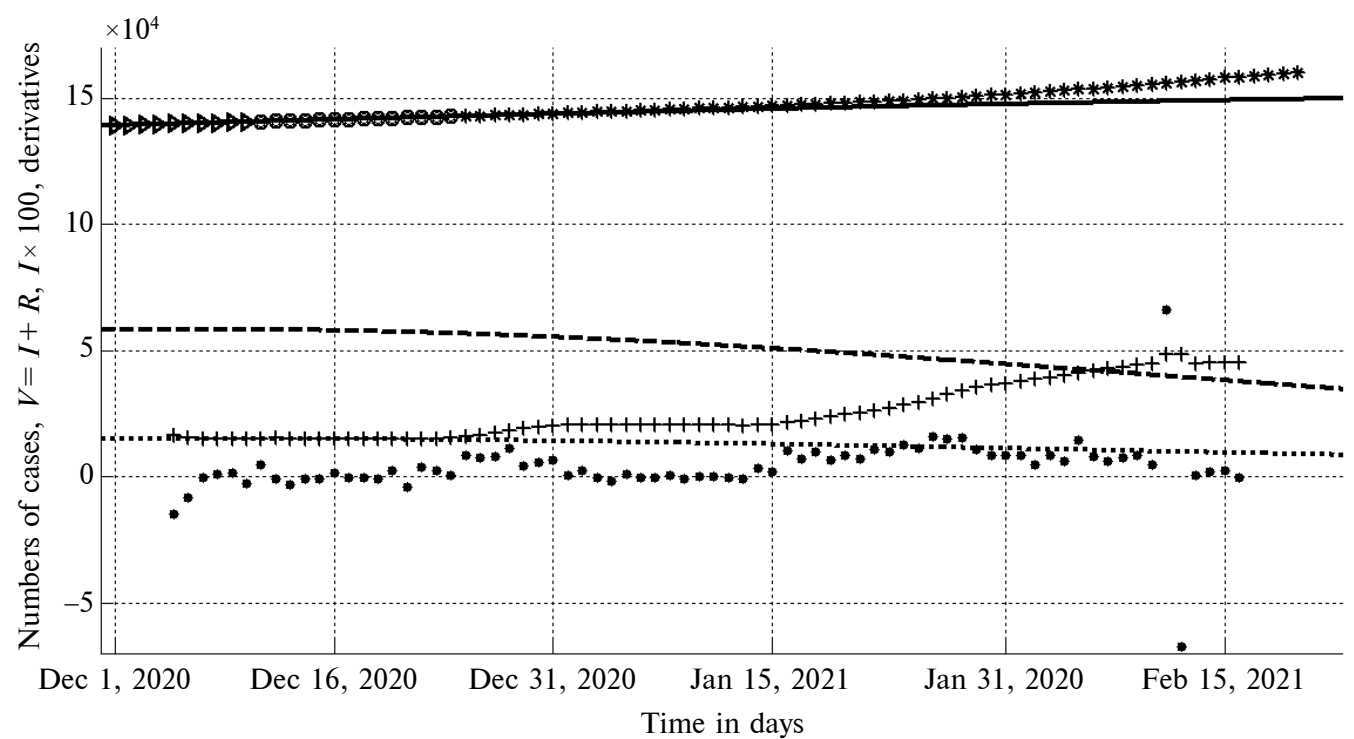

Figure 2: Pandemic dynamics in Qatar (markers) and SIR simulations (lines) calculated with the use of data sets from Tables 1 and 2. Numbers of victims $V(t)=I(t)+R(t)$ - solid lines; numbers of infected and spreading $I(t)$ multiplied by 100 - dashed; derivatives $d V / d t$ (eq. (13)) multiplied by 100 - dotted. Markers show accumulated numbers of cases $V_{j 3}$ from Table 1 and derivatives. "Circles" correspond to the accumulated numbers of cases taken for calculations (during period of time $T_{c}$ ); "triangles" - numbers of cases before $T_{c}$; "stars" - number of cases after $T_{c}$. "Crosses" show the first derivatives (eq. (2)) multiplied by 100, "dots" - the second derivative (eq. (3) ) multiplied by 1000

Table 2: Calculated optimal values of SIR parameters and other characteristics of the COVID-19 pandemic waves in Ukraine and Qatar

\begin{tabular}{cccc}
\hline Characteristics & $\begin{array}{c}\text { Ukraine, } 9^{\text {th }} \text { wave, } \\
i=9(J H U), V_{j 2}\end{array}$ & $\begin{array}{c}\text { Ukraine, } 9^{\text {th }} \text { wave, } i=9 \\
(\text { National statistics }), V_{j 1}\end{array}$ & $\begin{array}{c}\text { Qatar, } 2^{\text {nd }} \text { wave, } \\
i=2(J H U), V_{j 3}\end{array}$ \\
\hline$I_{i}$ & $62,384.6901000672$ & $59,686.0031221196$ & 581.685205791480 \\
$R_{i}$ & $830,900.452757076$ & $821,069.282592166$ & $140,084.171937066$ \\
$N_{i}$ & $1,524,200.0384$ & $2,037,235.2$ & 343,800 \\
$v_{i}$ & $580,121.592967068$ & $1,141,207.02807484$ & $203,678.101450066$ \\
$\alpha_{i}$ & $2.91326081249 \mathrm{e}-07$ & $1.55930616187218 \mathrm{e}-07$ & $1.26938469796243 \mathrm{e}-06$ \\
$\rho_{i}$ & 0.169004550327192 & 0.177949115084894 & 0.258545865290753 \\
$1 / \rho_{i}$ & 5.91700044799982 & 5.6195840003078 & 3.86778569781199 \\
$r_{i}$ & 0.998082602967150 & 0.998062592012312 & 0.999943364258809 \\
$F_{i}$, eq. $(23)$ & 3120.24523044173 & 3087.92417596763 & $105,931.169204818$ \\
$F_{i} / F_{C}\left(1, n_{i}-2\right)$ & 167.755119916222 & 166.017428815464 & 5695.22415079665 \\
$S_{i \infty}$ eq. $(11)$ & 347,782 & 810,539 & 188,661 \\
$V_{i \infty}$, eq. $(18)$ & $1,176,418$ & $1,226,696$ & 155,139 \\
Final day of the epidemic & June 15,2021 & July 14,2021 & January 16,2022 \\
wave, eq. $(19)$ & &
\end{tabular}

Lines in Fig. 1 illustrate the results of SIR simulations of the ninth epidemic wave in Ukraine obtained with the use of two data sets: national statistics [7, 8] (red) and data set reported by JHU [10] (black). Numbers of victims $V(t)=I(t)+R(t)$ (eq. (12)) are represented by solid lines. Numbers of infected and spreading the infection persons $I(t)$ are shown by dashed lines. Dotted lines represent the derivatives $d V / d t$ calculated with the use of eq. (13). This derivative yields the estimation of the daily number of new cases and can be compared with the calculations according to the formula (2) (crosses in Figs. 1 and 2). Fig. 1 illustrates that some discrepancies between red dotted line and red "crosses" appeared only after January 10. These deviations from the theoretical estimates can be explained by the New Year and Orthodox Christmas celebrations.

It can be seen that the accuracy of simulations based on the national statistics is rather good (the deviations between red "stars" and the red solid line are small). The use of JHU data sets yields worth accuracy. Nevertheless, the real numbers of cases already exceed the predicted saturations 
levels $V_{9 \infty}$ for both data sets and corresponding simulations. As of February 20, 2021 the national statistics yields the figure 1,304,456 of accumulated cases in Ukraine (see Table 1). Thus the epidemic observations during 58 days (after $T_{c}$ ) demonstrated only $6 \%$ exceeding of the saturation level in the case of national statistics.

Lines in Fig. 2 illustrate the results of SIR simulations for Qatar. Numbers of victims $V(t)=I(t)+R(t)$ (eq. (12)) are represented by the solid line. Numbers of infected and spreading the infection persons $I(t)$ are shown by the dashed line. The dotted line represents the derivatives $d V / d t$ calculated with the use of eq. (13). This derivative yields the estimation of the daily number of new cases and can be compared with the calculations according to the formula (2) ("crosses"). In comparison with the case of Ukraine the discrepancies between the dotted line and "crosses" appeared already after December 27 and show that new epidemic waves occurred in Qatar in 2021.

The deviations between "stars" and the solid line in Fig. 2 are not very large, but real numbers of cases already exceed the predicted saturations level $V_{2 \infty}$. As of February 20, 2021 the JHU yields the figure 159,967 of accumulated cases in Qatar (see Table 1). The corresponding value on the $V(t)$ curve is 149,512 . Thus the epidemic observations during 58 days (after $T_{c}$ ) demonstrated only $6.5 \%$ exceeding.

\section{Discussion}

It must be noted that the data presented in Table 1 does not show all the COVID-19 cases in Ukraine. Many infected persons are not identified, since they have no symptoms. For example, employees of two kindergartens and two schools in the Ukrainian city of Chmelnytskii were tested for antibodies to COVID-19 [15]. In total 292 people work in the surveyed institutions. Some of the staff had already fallen ill with COVID-19 or were hospitalized. Therefore, they were tested and registered accordingly. In the remaining tested 241 educators, antibodies were detected in 148 , or $61.4 \%$.
Many people know that they are ill, since they have similar symptoms as other members of families, but avoid making tests. Unfortunately, one laboratory confirmed case can correspond to several other cases which are not confirmed and displayed in the official statistics. Special simulations are necessary to take into account this data incompleteness.

The accurate estimation achieved in our study using the SIR model for Qatar new COVID-19 cases is mostly explained by the fact that the used data reflect in some extent the true reality of the spread of the virus in the country. Indeed, the massive daily number of tests performed allows detecting and reporting realistically the true number of COVID-19 cases. In addition the speed announcement of the result of tests helps to report these numbers without any delay reducing the errors in daily reporting.

\section{Conclusions}

Overall, presented results of SIR simulations indicate their high accuracy and allow us to make correct medium-term predictions about the expected number of cases and the number of people who spread the infection. The accuracy of longterm forecasts may be limited due to new waves of the epidemic. To improve their accuracy, new simulations must be performed with the use of fresher data sets. It is possible to use the approximate formulas in Chapter 13 of the book [4] to get quick estimates right of the final size and duration of an epidemic wave immediately after its start. We hope that the mass vaccination, which began in Qatar in late December 2020 (in Ukraine, this campaign started two months later) will be able to improve these forecasts. Comparing the results of calculations with the actual number of reported cases can be useful for assessing the effectiveness of vaccinations.

\section{Acknowledgements}

The authors are grateful to Oleksii Rodionov for his help in collecting and processing data.

\section{References}

[1] Nesteruk I. Simulations and predictions of COVID-19 pandemic with the use of SIR model. Innov Biosyst Bioeng. 2020;4(2):110-21. DOI: 10.20535/ibb.2020.4.2.204274

[2] Nesteruk I. Waves of COVID-19 pandemic. Detection and SIR simulations. medRxiv [Preprint] 2020. DOI: $10.1101 / 2020.08 .03 .20167098$

[3] Nesteruk I. COVID-19 pandemic dynamics in Ukraine after September 1, 2020. medRxiv [Preprint] 2020. DOI: $10.1101 / 2020.12 .21 .20248627$ 
[4] Nesteruk I. COVID-19 pandemic dynamics. Singapore: Springer; 2021. DOI: 10.1007/978-981-33-6416-5

[5] Fahmya AE, El-desoukya MM, Mohamed ASA. Epidemic analysis of COVID-19 in Egypt, Qatar and Saudi Arabia using the generalized SEIR model. medRxiv [Preprint] 2020. DOI: 10.1101/2020.08.19.20178129

[6] Ghanam R, Boone EL, Abdel-Salam G. SEIRD model for Qatar COVID-19 outbreak: A case study. arXiv [Preprint] 2020. arXiv: $2005.12777 \mathrm{v} 1$

[7] Coronavirus in Ukraine - Statistics [15.03.2021] - Map of infections, graphs [Internet]. Index.minfin.com.ua. 2021 [cited 2021 Mar 4]. Available from: https://index.minfin.com.ua/ua/reference/coronavirus/ukraine/

[8] Cabinet of Ministers of Ukraine - Home [Internet]. Kmu.gov.ua. 2021 [cited 2021 Mar 4]. Available from: https://www.kmu.gov.ua/

[9] Coronavirus Disease (COVID-19) Situation Reports [Internet]. Who.int. 2021 [cited 2021 Mar 4]. Available from: https://www.who.int/emergencies/diseases/novel-coronavirus-2019/situation-reports/

[10] COVID-19 Data Repository by the Center for Systems Science and Engineering (CSSE) at Johns Hopkins University [Internet]. GitHub. 2021 [cited 2021 Mar 4]. Available from: https://github.com/owid/covid-19-data/tree/master/public/data

[11] Kermack WO, McKendrick AG. A contribution to the mathematical theory of epidemics. J Royal Stat Soc Ser A. 1927;115(772):700-21. DOI: 10.1098/rspa.1927.0118

[12] Murray JD. Mathematical biology I/II. New York: Springer; 2002.

[13] Draper NR, Smith H. Applied regression analysis. 3rd ed. John Wiley; 1998.

[14] Statistical tables [Internet]. Onlinepubs.trb.org. 2021 [cited $2021 \mathrm{Mar} 4$ ]. Available from: https://onlinepubs.trb.org/onlinepubs/nchrp/cd-22/manual/v2appendixc.pdf

[15] An experiment with mass testing for COVID-19 was conducted in Khmelnytsky| Podillya News [Internet]. Podillya News | News of Khmelnytsky region. 2021 [cited 2021 Mar 4]. Available from: https://podillyanews.com/2020/12/17/u-shkolahhmelnytskogo-provely-eksperyment-z-testuvannyam-na-covid-19

\author{
І.Г. Нестерук ${ }^{1,2}$, Н. Бенлага ${ }^{3}$ \\ ${ }^{1}$ Інститут гідромеханіки НАН України, Київ, Україна \\ ${ }^{2}$ КП ім. Ігоря Сікорського, Київ, Україна \\ ${ }^{3}$ Катарський університет, Доха, Катар
}

\title{
ПРОГНОЗИ ДИНАМІКИ ПАНДЕМІЇ COVID-19 В УКРАÏHI ТА КАТАРІ НА ОСНОВІ УЗАГАЛЬНЕНОÏ SIR-МОДЕЛІ
}

Проблематика. Для моделювання збільшення кількості випадків COVID-19 із часом можна використовувати різні набори даних і різні математичні моделі. Оскільки в статистичних даних існують деякі відмінності, то результати моделювання можуть бути різними. Складні математичні моделі містять багато невідомих параметрів, значення яких необхідно визначати, використовуючи обмежену кількість спостережень за захворюванням у часі. Навіть довготривалий моніторинг епідемії може не дати надійних оцінок параметрів моделі через постійну зміну умов тестування, ізоляції заражених, умов карантину, мутації збудника, щеплення тощо. Тому необхідні більш прості підходи. Зокрема, попереднє моделювання динаміки епідемії COVID-19 в Україні базувалося на згладжуванні залежності кількості випадків від часу та узагальненій SIR-моделі (сприйнятливі-інфіковані-видалені). Ці підходи дали змогу виявити хвилі пандемії та розрахувати адекватні прогнози їх тривалості й кінцевих розмірів. Зокрема, було досліджено вісім хвиль пандемії COVID-19 в Україні.

Мета. Виявити зміни в динаміці пандемії та представити результати SIR-моделювання на основі української національної статистики та даних, повідомлених Університетом Джона Хопкінса (JHU) для України та Катару.

Методика реалізації. Ми використовуємо метод згладжування для залежності кількості випадків від часу, узагальнену SIRмодель для динаміки будь-якої епідемічної хвилі, точний розв'язок лінійних диференціальних рівнянь і статистичний підхід для ідентифікації параметрів моделі, що були запропоновані раніше.

Результати. Розраховано оптимальні значення параметрів SIR-моделі та представлено деякі прогнози щодо остаточного розміру й тривалості епідемій. Наведено відповідні SIR-криві та порівняння з реальною кількістю випадків.

Висновки. На жаль, наші прогнози не надто оптимістичні: в Україні нові випадки не перестануть з'являтися до червня-липня 2021 року; в Катарі нові випадки можуть з'являтися впродовж усього 2021 року. Очікувана велика тривалість пандемії змушує нас бути обережними та солідарними. Можливо, представлені результати можуть бути корисними для оцінки ефективності щеплень.

Ключові слова: пандемія COVID-19; динаміка епідемії в Україні; динаміка епідемії в Катарі; математичне моделювання інфекційних захворювань; SIR-модель; ідентифікація параметрів; статистичні методи.

\section{И.Г. Нестерук ${ }^{1,2}$, Н. Бенлага ${ }^{3}$}

${ }^{1}$ Институт гидромеханики НАН Украины, Киев, Украина

${ }^{2}$ КПИ им. Игоря Сикорского, Киев, Украина

${ }^{3}$ Катарский университет, Доха, Катар

\section{ПРОГНОЗЫ ДИНАМИКИ ПАНДЕМИИ COVID-19 В УКРАИНЕ И КАТАРЕ НА ОСНОВЕ ОБОБЩЕННОЙ SIR-MОДЕЛИ}

Проблематика. Чтобы смоделировать рост числа случаев COVID-19 со временем, можно использовать различные наборы данных и различные математические модели. Поскольку статистические данные содержат некоторые различия, то результаты 
моделирования могут быть разными. Сложные математические модели содержат множество неизвестных параметров, значения которых необходимо определять, используя ограниченное количество наблюдений за болезнью с течением времени. Даже длительный мониторинг эпидемии может не дать надежных оценок параметров модели из-за постоянного изменения условий тестирования, изоляции инфицированных, условий карантина, мутаций вируса, вакцинации и т.д. Следовательно, необходимы более простые подходы. В частности, предыдущее моделирование динамики эпидемии COVID-19 в Украине основывалось на сглаживании зависимости количества случаев от времени и обобщенной SIR-модели (восприимчивые-инфицированныеудаленные). Эти подходы позволили обнаружить волны пандемии и рассчитать адекватные прогнозы их продолжительности и окончательных размеров. В частности, были исследованы восемь волн пандемии COVID-19 в Украине.

Цель. Выявить изменения в динамике пандемии и представить результаты SIR-моделирования на основе национальной статистики Украины и данных, предоставленных Университетом Джона Хопкинса (JHU) для Украины и Катара.

Методика реализации. Мы используем метод сглаживания зависимостей числа случаев от времени, обобщенную SIR-модель для динамики произвольной волны эпидемии, точное решение линейных дифференциальных уравнений и статистический подход для идентификации параметров модели, которые были предложены ранее.

Результаты. Были рассчитаны оптимальные значения параметров SIR-модели и представлены прогнозы относительно окончательных размеров и продолжительности эпидемий. Приведены соответствующие SIR-кривые и сравнение с реальным числом случаев.

Выводы. К сожалению, наши прогнозы не очень оптимистичные: в Украине новые случаи не перестанут появляться до июняиюля 2021 года; в Катаре новые случаи заболевания могут появляться в течение всего 2021 года. Ожидаемая длительность пандемии заставляет нас проявлять осторожность и солидарность. Возможно, представленные результаты могут быть полезны для оценки эффрективности вакцинаций.

Ключевые слова: пандемия COVID-19; динамика эпидемии в Украине; динамика эпидемии в Катаре; математическое моделирование инфекционных заболеваний; SIR-модель; идентификация параметров; статистические методы. 